\title{
FOOD SECURITY STATUS: ITS DRIVERS AND COPING STRATEGIES AMONG VEGETABLE FARMING HOUSEHOLDS
}

\author{
Ridwan MUKAILA ${ }^{1, *}$, Abraham FALOLA², Olubunmi Abayomi OMOTESHO² \\ *E-mail: ridwan.mukaila@unn.edu.ng
}

Received: Oct. 23, 2020. Revised: Dec. 15, 2020. Accepted: Dec. 22, 2020. Published online: Jan. 29, 2021

\begin{abstract}
Food insecurity remains a major challenge worldwide, especially among the rural areas of developing nation. Women and children are most vulnerable to this phenomenon. However, while many studies have assessed farming households' food security status in general, there is dearth of information on vegetable farmers', who are mostly women, food security status in particular. This study, therefore, investigated the food security status of vegetable farming households, its drivers and coping strategies in Kwara State, Nigeria. Descriptive statistics, food insecurity index and logistic regression were used to analysed data collected from 180 respondents. The findings showed that food insecurity remains a major challenge in rural areas as only $45.55 \%$ were food secure. The food secure group surpassed the food security line by $17 \%$. Food insecure group fell below the food security line by $36 \%$ with a daily average calorie intake of 1581.35 kcal. Annual income $(p<0.1)$, cooperative membership $(p<0.1)$, vegetable production $(p<0.05)$
\end{abstract}

and access to credit $(p<0.05)$ were the significant factors enhancing their food security status, while household size $(p<0.01)$ negatively influenced it. The widely used food insecurity coping mechanisms by the households were eating less expensive food, eating wild fruits, reducing rational consumption, allowing children to eat first, borrowing money to buy food, buying food on credit and skipping meal within a day. The study recommends encouragement of vegetable production through provision of credit facilities to the farmers as this would enhance their food security status.

Keywords: food insecurity; calorie intake; rural women; coping strategies; vegetable production.

\section{INTRODUCTION}

Food insecurity is a global phenomenon. According to Food and Agricultural Organization (2019), more than 820 million people are

\footnotetext{
${ }^{1}$ Department of Agricultural Economics, University of Nigeria, Nsukka, Enugu State, Nigeria

2 Department of Agricultural Economics and Farm Management, University of Ilorin, Kwara State, Nigeria
} 


\section{FOOD SECURITY STATUS OF VEGETABLE FARMING HOUSEHOLDS}

undernourished globally. By 2050, the world population will be around 9 billion; this is challenging as it will require $70 \%$ more food to meet with the increase in population (King et al., 2017). Food is the number one human need for survival. Despite many efforts to improve and increase food production and quality globally, many citizens of Africa and Asia have died due to malnutrition (Matemilola and Elegbede, 2017).

One of the major problems facing developing nations is food insecurity, as about 779.9 million people in developing countries are food insecure (FAO, IFAD and WFP, 2015). It is well known that most African countries are still food insecure and Nigeria is part of this phenomenon. Achieving food security in Africa is still a challenge, about 232.5 million people are undernourished in Africa (FAO, IFAD and WFP, 2015). The level of food insecurity keeps increasing in Africa as about 181.7 million people are food insecure in 1990, 210 million in 2000, 213 million in 2005, 218.5 million in 2010 and 232.5 million in 2014-16 (FAO, 2016). In West Africa, about 33.7 million are food insecure (FAO, IFAD and WFP, 2015).

According to current statistics, in Nigeria alone, about 24.6 million people were undernourished between 2017-2019, while 17.8 million people faced severe food insecurity problem between 2017-2019 (FAO, 2020). The rural areas are the most hit in terms of food insecurity, as food insecurity was reported to be more endemic in rural areas (Nigeria MDGs End-point report, 2015). The problem of food insecurity in Nigeria has been in existence for long as back as the 1970's, when the agricultural sector was neglected for the oil sector. Since then, many government programmes have been developed to tackle food insecurity problem yet the food insecurity problem seems increasing alongside with increase in population. Endpoint reports of Nigeria MDGs also show that Nigeria missed most of the indicators of fighting against hunger in the MDGs, although Nigeria made some progress, but was unable to halve the number of hungry people in 2015 (Nigeria MDGs End-point report, 2015). This shows food insecurity is still a major problem facing the country. This inability to meet this target implies that a lot of efforts, especially in the agricultural sector, have to be made for the country to achieve the second Sustainable Development Goal of the United Nations development programme of having zero hunger by 2030 .

Among the important crops in the country are vegetables. They are commonly grown in rural areas and are very important to the diet of the rural dwellers and Nigeria as a whole. The vegetables supply several nutrients, such as vitamins, potassium, magnesium, calcium, folate, iron, beta-carotene, dietary fibre and other nutrients that contribute to a healthy life of the people. Vegetable farming is widely dominated by female farmers who are vulnerable to the problem of food insecurity. 


\section{R. MUKAILA, A. FALOLA, O. OMOTESHO}

Several studies have reported that vegetables can play a vital role in solving global micronutrient crisis and source of additional income to the rural dwellers (Tsiboe et al., 2019; Yusuf and Abbas, 2012). Similarly, several studies have considered the food security status of farming households in general (Omotesho, 2006; Babatunde et al., 2007; Babatunde and Qaim, 2010; Oyebanjo, 2013; Obasan, 2017). However, studies that specifically focus on vegetable farming households' food security status are non-existent. Therefore, this study filled the gap by assessing the food security status of vegetable farming households in Kwara State, Nigeria. Specifically, this study described the socioeconomic profile of vegetable farmers; assessed vegetable farming households' food security status; identified the drivers of their food security status; and examined their food insecurity coping strategies.

\section{MATERIALS AND METHODS}

\section{Study area}

This research was carried out in Kwara State, Nigeria. The state is located in the North Central geopolitical zone of the country, with latitudes $7^{\circ} 45^{\prime} \mathrm{N}$ to $9^{\circ} 30^{\prime} \mathrm{N}$ and longitude $2^{\circ} 30^{\prime} \mathrm{E}$ to $6^{\circ} 25^{\prime} \mathrm{E}$. The state has a total land area of 36,825 $\mathrm{km}^{2}$ (National Population Commission, 2006). Agriculture accounted for about $70 \%$ of the state workforce. The state is grouped into four zones (A, B, C and D) based on agronomic characteristics. As regards vegetable production, most of the farmers grow green amaranth, fluke pumpkin, jute, tomatoes, pepper, okra, onions and waterleaf.

\section{Sampling and data collection}

A four-stage sampling procedure was employed to select the respondents for this research. The first stage was a purposive selection of Zone $\mathrm{C}$ and Zone $D$ based on the preponderance of vegetable farmers in the zones. Thereafter, two Local Governments Areas (LGAs) were selected randomly from each zone, making four LGAs. In the third stage, five villages were randomly selected from each LGA, making 20 villages. In the final stage of the sampling technique, nine households were selected randomly from each village, thus making 180 households for this study.

The population for this study was made up of the vegetable farming households in the state. Primary data were collected from the vegetable farmers using structured questionnaire coupled with an interview schedule. The data covered information such as their socioeconomic characteristics, farming households' decision to vegetable production, food consumed by households (calorie intake of households), among others.

\section{Data analysis}

Descriptive statistics, food security indices and logistic regression were employed in analysing the data. The food security indices proposed by FAO was utilised to assess the food security status of vegetable farming households. This has been used by researchers (Omotesho et al., 2006) in studies on food security. A daily recommendation level of $2500 \mathrm{kcal}$ per capita was used as the food security line (FAO, 2005). Household members that took below 2500 kcal were categorised as food insecure and equal or above households were categorised otherwise. 


\section{FOOD SECURITY STATUS OF VEGETABLE FARMING HOUSEHOLDS}

$$
\text { Food security index }=\frac{\text { Daily Household's per capita calorie consumed }}{\text { Daily Household's per capita calorie requirement }}
$$

The Headcount ratio (HR) is a measure of food security status and it is expressed as:

$$
\mathrm{HR}=\frac{\mathrm{M}}{\mathrm{N}}
$$

where, $\mathrm{M}$ is the number of the foodinsecure and $\mathrm{N}$ is the sample population. Food insecurity Gap is specified as:

$$
\mathrm{FIG}_{\mathrm{i}}=\frac{\mathrm{TCR}_{\mathrm{i}}-\mathrm{TCC}_{\mathrm{i}}}{\mathrm{TCR}_{\mathrm{i}}}
$$

The total food insecurity gap or shortfall index is expressed as:

$$
\mathrm{TFIG}=\frac{\Sigma\left(\mathrm{TCR}_{\mathrm{i}}-\mathrm{TCC}_{\mathrm{i}}\right)}{\mathrm{TCR}_{\mathrm{i}}}
$$

where, $F G_{i}$ is the Food insecurity Gap of $\mathrm{i}^{\text {th }}$ food insecure household, TCC $_{i}$ is the Total calorie consumption by $\mathrm{i}^{\text {th }}$ food

$$
Y=\beta_{0}+\beta_{1} G+\beta_{2} A+\beta_{3} H H+\beta_{4} E d+\beta_{5} C M+\beta_{6} M O+\beta_{7} A l+\beta_{8} A C+e
$$

where, $Y$ is the Food security indicator (food secure household $=1$, Food insecure household $=0$ ), $G$ is the gender of household head ( 1 = male, $0=$ female), $A$ is the age of household head (years), $\mathrm{HH}$ is the household size (Adult equivalent), $\mathrm{Ed}$ is the educational level (years), CM is the cooperative membership $(1=$ yes, $0=$ no), $\mathrm{MO}$ is the major occupation (vegetable production $=1$, otherwise $=0$ ), $\mathrm{Al}$ is the annual income ( $\mathrm{N}), \mathrm{AC}$ is the access to credit ( $\#$ ) and $e$ is the error term. A Likert rating scale was used to identify the widely used food insecurity coping strategies among vegetable farming households. A three-point Likert scale (regular $=3$, occasionally $=2$ and never $=1$ ) with a mean score of 2.0 was used as a cut-point for mostly used food insecurity coping strategies. Therefore, any household means score equal to or greater than 2.0 was considered widely used food insecurity coping strategies.

A weighted score was further used to rank food insecurity coping strategies. insecure household and $\mathrm{TCR}_{\mathrm{i}}$ is the Total calorie requirement for $i^{\text {th }}$ food insecure household.

Square food insecure Gap: this indicate the severity of food insecurity among the food insecure household and it is expressed as:

$$
\mathrm{SFIG}=\frac{\Sigma\left(\mathrm{FIG}_{\mathrm{i}}\right)^{2}}{\mathrm{M}}
$$

The logistic regression was used to determine the factors influencing food security of the respondents. This was employed in line with the study of Omotesho et al. (2006), Babatunde et al. (2007), Oyebanjo et al. (2013), Obasan et al. (2017). It is explicitly expressed as:

The weighted score was calculated using the formula:

$$
3(f)+2(f)+1(f)
$$

where, $f$ is the frequency for each food insecurity coping strategies.

\section{RESULTS AND DISCUSSION}

\section{Socio-economic characteristics of vegetable farmers}

Table 1 presents the socioeconomic profiles of vegetable farmers. The majority of the vegetable farmers were female, which accounted for about $89 \%$ of the respondents. This implies that vegetable production is a female dominated ventures. It could be observed that a larger proportion (35.56\%) of the vegetable farmers falls within the age of 51 to 60 year with an average age of 54 years. This shows that the vegetable farmers were 


\section{R. MUKAILA, A. FALOLA, O. OMOTESHO}

quite advanced in age though still active to perform farming activities. In terms of the drudgery associated with peasant agriculture, age is an important factor when considering the quality and type of labour available on the farm. Regarding the educational status of the respondents, $41.67 \%$ of the vegetable farmers did not have formal education while only $22.1 \%$ and 5\% had secondary and tertiary education, respectively (Table 1). This suggests that the level of formal education among the farmers was low.

The household size distribution of respondents was measured in adult equivalent (AE). This was done to capture their food security status in terms of calories intake per adult equivalent and to convert the available family labour to adult equivalent. The majority $(55.6 \%)$ of the vegetable farmers had a household size greater than six adult equivalents, they had an average household size of seven persons per household (Table 1). This shows that the household had enough members to use as family labour in vegetable farming. The larger household size is not surprising as rural household love to have a larger household size to be used as cheap family labour. The majority of the vegetable farmers (51.11\%) had an annual income between $\$ 100,001$ (USD 262.81) to $\$ 200,000$ (USD 525.62). The vegetable farmers had an average annual income of $\$ 128,377.78$ (USD 3,312.98) with vegetable farming accounting for a larger proportion of their annual income. Regarding the farm size, the majority of the vegetable farmers (83.89\%) had below 2.4 hectares of farmland. They had an average farm size of 1.7 hectares, this implies that the farmers were operating on smallscale farming. This is in line with the findings of Wakil et al. (2018), who reported that vegetable farmers had a small farm size lower than 2 hectares.

The majority (81.67\%) of the vegetable farmers did not belong to a cooperative society, while only a few were members of cooperative society (Table 1). This contributed to their low access to credit, as a cooperative society can make available and accessible credit to them. Similarly, the majority (73.33\%) of them cannot access credit. This high level of lack of access to credit suggests that getting credit is a challenge to these rural farmers. The majority of them (79.44\%) had vegetable farming as their major occupation. Their average farming experience was 21 years, this suggests that the vegetable farmers can be described as experienced farmers, who are knowledgeable about its farming activities. It also suggests that vegetable production is not a new venture in the study area.

\section{Calorie intake distribution of households}

Table 2 shows the distribution of households' daily calorie consumption per adult equivalent. The larger proportion $(47.22 \%)$ of the farmers had a per capita food consumption of $1000-2000 \mathrm{kcal} / \mathrm{day} / \mathrm{AE}, 7.22 \%$ of the farmers had a per capita consumption of $2001-2499$ and $45.56 \%$ of the farmers consumed $2500 \mathrm{kcal} / \mathrm{day} / \mathrm{AE}$ 


\section{FOOD SECURITY STATUS OF VEGETABLE FARMING HOUSEHOLDS}

and above. This implies that the which is the recommended rate by majority of the household consumed

FAO.

less than 2500kcal per capita per day,

Table 1 - Socio-economic profile of the respondents

\begin{tabular}{|c|c|c|c|}
\hline Variables & Frequency & Percentage & Mean \\
\hline \multicolumn{4}{|l|}{ Gender of farmers } \\
\hline Male & 19 & 10.55 & \\
\hline Female & 161 & 89.45 & \\
\hline Age & & & 54 \\
\hline $30-40$ & 26 & 14.44 & \\
\hline $41-50$ & 34 & 18.89 & \\
\hline $51-60$ & 64 & 35.56 & \\
\hline$>60$ & 56 & 31.11 & \\
\hline \multicolumn{4}{|l|}{ Education } \\
\hline No formal education & 75 & 41.67 & \\
\hline Primary education & 58 & 32.22 & \\
\hline Secondary education & 38 & 21.11 & \\
\hline Tertiary education & 9 & 5 & \\
\hline Household size (AE) & & & 7.14 \\
\hline $2-6$ & 80 & 44.44 & \\
\hline$>6$ & 100 & 55.56 & \\
\hline 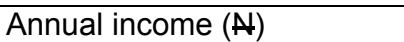 & & & $128,377.78$ \\
\hline$<100,000$ & 80 & 44.44 & \\
\hline $100,001-200,000$ & 92 & 51.11 & \\
\hline $200,001-300,000$ & 6 & 3.33 & \\
\hline $300,001-400,000$ & 1 & 0.56 & \\
\hline$>400,001$ & 1 & 0.56 & \\
\hline Farm size (hectare) & & & 1.79 \\
\hline $0.4-2.39$ & 151 & 83.89 & \\
\hline 2.4-3.99 & 22 & 12.22 & \\
\hline$>4$ & 7 & 3.89 & \\
\hline \multicolumn{4}{|l|}{ Cooperative membership } \\
\hline Non-member & 147 & 81.67 & \\
\hline Member & 33 & 18.33 & \\
\hline \multicolumn{4}{|l|}{ Access to credit } \\
\hline Without access & 132 & 73.33 & \\
\hline With access & 48 & 26.67 & \\
\hline \multicolumn{4}{|l|}{ Primary occupation } \\
\hline Farming & 143 & 79.44 & \\
\hline Civil servant & 4 & 2.22 & \\
\hline Trading & 26 & 14.44 & \\
\hline Artisan & 7 & 3.89 & \\
\hline Farming experience (years) & & & 21 \\
\hline$<10$ & 41 & 22.78 & \\
\hline $11-20$ & 54 & 30 & \\
\hline $21-30$ & 40 & 22.22 & \\
\hline$>30$ & 45 & 25 & \\
\hline
\end{tabular}

Source: Computed from field survey 


\section{R. MUKAILA, A. FALOLA, O. OMOTESHO}

Table 2 - Calorie intake distribution of household members

\begin{tabular}{ccc}
\hline Calorie intake (kcal/AE/day) & Frequency & Percentage \\
\hline $1000-2000$ & 85 & 47.22 \\
\hline $2001-2499$ & 13 & 7.22 \\
\hline$>2500$ & 82 & 45.56 \\
\hline Total & $\mathbf{1 8 0}$ & $\mathbf{1 0 0}$ \\
\hline
\end{tabular}

Source: Field survey

Distribution of household members based on their food security status

The distribution of households based on their food security status in the study area is presented in Table 3. Household food security status is based on the daily recommendation of $2500 \mathrm{kcal} / \mathrm{AE} / \mathrm{per}$. Any household that consumed $2500 \mathrm{kcal} / \mathrm{AE} / \mathrm{day}$ and above were considered food secure, while household that consumed less than $2500 \mathrm{kcal} / \mathrm{AE} /$ day were considered food insecure. As shown in Table 3, $45.55 \%$ of the households were food secure, while $54.4 \%$ werefood insecure. These findings imply that the majority of the vegetable farmer households in the study area are food insecure.

Table 3 - Distribution of household members based on their food security status

\begin{tabular}{ccc}
\hline $\begin{array}{c}\text { Food } \\
\text { security } \\
\text { status }\end{array}$ & Frequency & Percentage \\
\hline food insecure & 98 & 54.45 \\
\hline food secure & 82 & 45.55 \\
\hline
\end{tabular}

Source: Field survey

\section{Summary of food security indices}

Table 4 summarized the food security indices of the households. As shown in Table 4, the study area could be classified as food insecure as only $45.55 \%$ met the daily recommendation of 2500 kcal intake per adult equivalent, while $54.45 \%$ were food insecure, feeding below the daily recommendation. The average household size of food secure households was five persons, while the food insecure households had nine persons on average. This implies that households with small household size were food secure while those with higher household size were food insecure. The surplus/shortfall index which measures the depth of food insecurity or the level of divergence from the food security line indicates that the food secure households exceeded the calorie requirement by 17\% (Table 4). The food insecure households fell short of the required daily calorie intake by $36 \%$. Square food insecure gap or square shortfall index is 0.01 . Headcount ratio of 0.46 implies that $46 \%$ of individuals in the study area are food secure, while $54 \%$ were food insecure leaving below the daily required calorie intake of 2500 kcal. The average calorie available (AE/day) for food-secure households was $2935.54 \mathrm{kcal}$, while average calorie available (AE/day) for foodinsecure households was $1581.35 \mathrm{kcal}$ (Table 4). This implies that the foodinsecure households were feeding on a low calorie daily despite farming activities required enough energy for its effective operation 


\section{FOOD SECURITY STATUS OF VEGETABLE FARMING HOUSEHOLDS}

Table 4 - Summary of Indices of food security

\begin{tabular}{llll}
\hline Food security indices & Food secure & Food insecure & All \\
\hline Percentage household & 45.55 & 54.45 & 100 \\
\hline Average household size (AE) & 5.34 & 8.63 & 7.14 \\
\hline Surplus/shortfall index & 0.17 & 0.36 & \\
\hline Square food insecure Gap & & 0.01 & \\
\hline Head count ratio & 0.46 & 0.54 & 2192.05 \\
\hline $\begin{array}{l}\text { Average calorie available } \\
\text { (AE/day) }\end{array}$ & 2935.5 & 1581.35 & \\
\hline
\end{tabular}

Source: Field survey

Drivers of food security status of the vegetable farming households

The result of the logistic regression used to examine factors influencing the food security status of rural vegetable farming households is presented in Table 5. The table shows that the model has a good fit as reflected by a highly significant $(p<0.001)$ LR chi-square value of 57.99. The coefficient of vegetable production was positively significant $(p<0.05)$. This suggests that a proportionate increase in vegetable production increased the probability of being food secure. Vegetable production plays a significant role in the food security status of rural households, it serves as a readily available source of nutrients, such as vitamins, potassium, magnesium, iron, beta-carotene, dietary fibre, folate and other nutrients that contribute to a healthy life of the households. Consuming vegetables produced by the households will improve their nutritional status and enhance their food security level. This is because food security is not only about consuming food to fill the stomach, but to eat nutritional food for their healthy life. Similarly, income derived from vegetable production can be used to purchase food items that were not produced by the farmers.

Table 5 - Drivers of food security status of the vegetable farmers

\begin{tabular}{llll}
\hline Variables & Coef. & Stand. err. & t-value \\
\hline Gender & -0.6506 & 0.6076 & -1.0700 \\
\hline Age & 0.0092 & 0.0200 & 0.4600 \\
\hline Household size (AE) & -0.3191 & 0.0886 & $-3.6000^{* * *}$ \\
\hline Education & 0.0394 & 0.2176 & 0.1800 \\
\hline Cooperative membership & 0.8877 & 0.4884 & $1.8200^{*}$ \\
\hline Vegetable production & 0.8375 & 0.3768 & $2.2200^{* *}$ \\
\hline Annual income & 0.0000 & 0.0000 & $1.9100^{*}$ \\
\hline Access to credit & 0.7504 & 0.3697 & $2.0300^{* *}$ \\
\hline Constant & 1.1699 & 1.5852 & 0.7400 \\
\hline
\end{tabular}

Pseudo $\mathrm{R}^{2}=24 \%, \mathrm{LR} \mathrm{chi}^{2}=57.99, \mathrm{Prob}>\mathrm{chi}^{2}=0.0000 ;{ }^{* *} p<0.01,{ }^{* *} p<0.05,{ }^{*} p<0.1$;

Source: Field survey 


\section{R. MUKAILA, A. FALOLA, O. OMOTESHO}

The coefficient of household size negatively influenced food security status $(p<0.01)$. This implies that households with smaller size have a greater tendency of being food secure, compared to those with larger size (Table 5). This conforms with the findings of Omotesho et al. (2006), Oyebanjo et al. (2013), Frimpong and Asuming-Brempong (2013), Obasan et al. (2017) that the households with few members were more food secure.

Cooperative membership was positively significant $(p<0.1)$. This suggests that vegetable farmers who belong to cooperative societies are likely to be food secure than those who did not. This could be due to the financial and material support that such households could receive from cooperatives, which those who are not members may not. Oyebanjo et al. (2013) reported the same thing that cooperative membership influence food security positively.

Annual income influenced food security status positively at $10 \%$ (Table 5). This result implies that household heads with high annual income are more likely to be food secure compared to low-income ones. Higher-income household heads may probably have much money to procure food items for consumption, while a household with lower income will have less to spend on consumption. This conforms with the findings of Omotesho et al. (2006), Muche and Tadele (2015), Obasan etal. (2017) that income influenced the food security status of people positively. The coefficient of access to credit was positive in relation to food security status (Table 5). Vegetable farmers that have access to credit can use such credit to increase their farming production. This will, in turn, better-off their food security status. This conforms with the findings of Frimpong and Asuming-Brempong (2013) that access to credit influenced food security positively.

\section{Food insecurity coping strategies adopted by the respondents}

Table 6 presents the coping strategies used by households against food insecurity. Table 6 revealed that eating less expensive and preferred food was widely employed to cope with food insecurity among vegetable farming households and was ranked first. This suggests that the households purchased less expensive food for them to have enough food in their households. This is in coherent with the findings of Akerele et al. (2013), who reported that eating less expensive food was ranked first among the coping strategies. Using this strategy could be related to lowerincome status of the rural people and large household size, which requires a lot of food to feed them. Eating wild fruits was used by the majority as food insecurity coping strategy among the households. The children gathered and eat fruits such as mango, almond to cope with food insecurity.

Table 6 further shows that reducing rational consumption was also widely adopted by rural households and was ranked third among the coping strategies. This 


\section{FOOD SECURITY STATUS OF VEGETABLE FARMING HOUSEHOLDS}

implies that the households limit their meal portion size to cope with food insecurity. Allowing children to eat first before other members of the households was ranked fourth, followed by borrowing money to buy food. The adults allow the children to eat first because the children cannot endure starvation. Buying food on credit was ranked sixth, the household head purchase food on credit to avoid the severe effect of food insecurity. Though at a little higher price than the actual price, but it assisted the households in coping with the food insecurity. Skipping meal within a day was ranked seventh, this was done when the households had little foodstuff available. This was widely practised by the adults where they skip lunch to cope with the food insecurity. Selling of assets, picking up left-over food at social functions and skipping meals for a whole day were the less ranked among the food insecurity coping mechanism used by the vegetable farming households. It is worth knowing that the last three food insecurity coping strategies had a Likert mean score lower than 2.0, which was the cut-point, therefore, they were not widely used.

Table 6 - Food insecurity coping mechanisms adopted by the households

\begin{tabular}{llllll}
\hline Coping strategies & $\begin{array}{l}\text { Regularly } \\
\text { freq. (\%) }\end{array}$ & $\begin{array}{l}\text { Occasional } \\
\text { freq. (\%) }\end{array}$ & $\begin{array}{l}\text { Never } \\
\text { freq. (\%) }\end{array}$ & WS & LM \\
\hline Eating less expensive food & $96(53.33)$ & $67(37.22)$ & $17(9.44)$ & 439 & 2.44 \\
\hline Eating wild fruits & $\begin{array}{l}102 \\
(56.67)\end{array}$ & $19(10.56)$ & $59(32.78)$ & 403 & 2.24 \\
\hline Reducing rational consumption & $89(49.44)$ & $33(18.33)$ & $58(32.22)$ & 391 & 2.17 \\
\hline Allowing children to eat first & $68(37.78)$ & $69(38.33)$ & $43(23.89)$ & 385 & 2.14 \\
\hline Borrowing money to buy food & $87(48.33)$ & $22(12.22)$ & $71(39.44)$ & 376 & 2.09 \\
\hline Buying food on credit & $84(46.67)$ & $16(8.89)$ & $80(44.44)$ & 364 & 2.02 \\
\hline Skipping meal within a day & $75(41.67))$ & $31(17.22)$ & $74(41.11)$ & 361 & 2.01 \\
\hline Selling of assets & $38(21.11)$ & $4(2.22)$ & $138(76.67)$ & 260 & 1.44 \\
\hline $\begin{array}{l}\text { Picking up left-over food at social } \\
\text { functions }\end{array}$ & $20(11.11)$ & $10(5.56)$ & $\begin{array}{l}151 \\
(83.89)\end{array}$ & 231 & 1.28 \\
\hline Skipping meals for a whole day & $1(0.56)$ & $13(7.22)$ & $166(93.22)$ & 195 & 1.08 \\
\hline
\end{tabular}

Freq. $=$ frequency, $\mathrm{WS}=$ weighted score, $\mathrm{LM}=$ Likert mean; Source: Field survey

\section{CONCLUSIONS}

This research focused on the food security status of vegetable farming households, their drivers and coping strategies in Kwara State, Nigeria. The findings revealed that more than half of the vegetable farming households were food insecure suggesting that food insecurity is still a major challenge in the rural area. Vegetable production is a major determinant and contributes significantly to the improvement of food security status. The other positive drivers, which improve the vegetable farming households' food security in the rural areas, were annual income, cooperative membership and credit access, while household size influenced their food security status negatively. 


\section{R. MUKAILA, A. FALOLA, O. OMOTESHO}

The households with a smaller household size or members were more food secure, while those with larger household size were food insecure. It can be inferred from this study that vegetable production plays a significant role in improving the food security status of rural households and can be used as a tool for improving households food security in Nigeria. Therefore, in achieving food security in Nigeria, especially in the rural households, it is pertinent that there should be a closer look into the specified significant factors that influenced food security stated above to ensure food security.

This study further revealed that the widely engage food insecurity coping strategies by the households were eating less expensive food, eating wild fruits, reducing rational consumption, allowing children to eat first before other members of the households, buying food on credit, borrowing money to buy food and skipping meal within a day. This study recommends that measures that will improve the food security status of the rural farmers should be put in place. To achieve this, the farmers need to form or join cooperative societies where they can pool their resources for productive ventures, access credit and enjoy economies of scale. Besides, governments, banks and non-governmental organisation should provide vegetable farmers with credit farmers, as this will not only boost their production, but also improve their economic and food security status. Also, effective household size management and enlightenment programmes on modern family planning methods should be encouraged in the study area.

\section{REFERENCES}

Akerele, D., Momoh, S., Aromolaran, A., Oguntona, C. \& Shittu, M. (2013). Food insecurity and coping strategies in South-West Nigeria. Food Security, 3: 407-414.

Babatunde, R.O., Omotesho, O.A., \& Sholotan, O. S. (2007). Socioeconomics characteristics and food security status of farming households in Kwara State, North-Central Nigeria. Pakistan J.Nutr., 6(1): 49-58.

Babatunde, R.O. \& Qaim, M. (2010). Impact of off-farm income on food security and nutrition in Nigeria by impact of off-farm income on food security and nutrition in Nigeria. Conference proceedings of Africa Association of Agricultural Economists, "Africa and the Global Food and Financial Crises", Sept. 19-23, Cape Town, South Africa.

FAO, IFAD and WFP. (2015). The State of Food Insecurity in the World 2015. Meeting the 2015 international hunger targets: taking stock of uneven progress. Rome, FAO.

FAO (2016). The state of food insecurity in the world. Food and Agricultural Organization of the United Nations. Rome, FAO.

FAO, IFAD, UNICEF, WFP and WHO. (2019). The State of Food Security and Nutrition in the World (SOFI): Safeguarding against economic slowdowns and downturns. Rome, FAO. Licence: CC BY-NC-SA 3.0 IGO.

Food and Agriculture Organisation Statistics (2020). Nigeria: Hunger and food insecurity. Food and Agricultural Organisation of the 


\section{FOOD SECURITY STATUS OF VEGETABLE FARMING HOUSEHOLDS}

United Nation, http://www.fao.org/ faostat/en/\#country/159 [Access 13 Oct. 2020]

Frimpong, S. \& Asuming-Brempong, S. (2013). Comparative study of determinants of food security in rural and urban households of Ashanti Region, Ghana. Int.J.Econ.Manag. Sci., 2(10): 29-42.

King, T., Cole, M., Farber, J.M., Eisenbrand, G., Zabaras, D., Fox, E.M. \& Hill, J.P. (2017). Food safety for food security: relationship between global megatrends and developments in food safety. Trends Food Sci.Tech., 68: 160-175, DOI: 10.1016/j.tifs.2017.08.014

Matemilola, S. \& Elegbede, I. (2017). The challenges of food security in Nigeria. Open Access Library Journal, 4(12): 1-22, DOI: 10.4236/oalib.1104 185

Muche, M. \& Tadele, E. (2015). Analysis of household level determinants of food security in Jimma zone, Ethiopia. J.Econ.Sustain.Dev., 6(9): 230-241.

National Population Commission (2006). National population and housing survey. National Population Commission, Abuja, Nigeria.

Nigeria Millennium Development Goals (MDGs). End-point report (2015). UNDP in Nigeria. https://www.ng. undp.org/content/nigeria/en/home/lib rary/mdg/nigeria-mdgs-end-point-rep ort-2015.html [Access 11 Jan. 2019]

Obasan, T.A., Okojie, L.O. \& Okuneye, P.A. (2017). Determinants of rural households' food security in Ogun State, Nigeria. In: Conference Proceedings of the $18^{\text {th }}$ Annual National Conference of The Nigerian Association of Agricultural Economists Held Al Federal University of Agriculture, Abeokuta, Nigeria, 16-19 $9^{\text {th }}$ Oct. 2017.

Omotesho, O.A., Adewumi, M.O. \& Ayinde, O.E. (2006). Determinants of food security among the rural farming households in Kwara State, Nigeria. African J.Gen.Agric., 2(1): 7-15.

Oyebanjo, O., Ambali, O.I. \& Akerele, E.O. (2013). Determinants of food security status and incidence of food insecurity among rural farming households in ljebu Division of Ogun State, Nigeria. J.Agric.Sci.Environ., 13: 92-103.

Tsiboe, F., Asravor, J. \& Osei, E. (2019). Vegetable production technical efficiency and technology gaps in Ghana. African J.Agric.Res.Econ., 14(4): 255-278, DOI: 10.22004/ag. econ.301046

Wakil, M., Sulum, A.A. \& Ibrahim, I. (2018). Assessment of women participation in vegetable production in Jere local government area of Borno state. J.Agric. Rural Res., 2(4): 96-102.

Yusuf, O.R. \& Abbas, I.I. (2012). Variation in vegetable production among urban farmers in llorin, Kwara State, Nigeria. Int.J.Dev. Sustain., 1(3): 1158-1169. 